Case Series

\title{
Experiences with mucormycosis during COVID times in a government hospital in Kerala - a case series
}

\section{Sarada Sreenath*, Anil Kumar Arupathuparayil Ravi}

Department of ENT, General Hospital, Ernakulam, Kerala, India

Received: 19 January 2022

Accepted: 01 February 2022

\section{*Correspondence:}

Dr. Sarada Sreenath,

E-mail: drsaradasree@gmail.com

Copyright: @ the author(s), publisher and licensee Medip Academy. This is an open-access article distributed under the terms of the Creative Commons Attribution Non-Commercial License, which permits unrestricted non-commercial use, distribution, and reproduction in any medium, provided the original work is properly cited.

\begin{abstract}
Mucormycosis is a rare invasive fungal infection which is often fatal. At the time of COVID-19 pandemic, there has been a sudden increase in the number of reported cases of mucormycosis. In this case series 10 cases of mucormycosis presented in our hospital during the COVID season are discussed. Of the 10 cases, only 8 patients had history of COVID infection. The predominant comorbidity was diabetes which was detected in all except one patient. But with timely diagnosis and appropriate management majority of the patients survived. Lesser symptoms and better prognosis were observed in patients without previous history of COVID.
\end{abstract}

Keywords: Mucormycosis, COVID, Fungal infection

\section{INTRODUCTION}

The occurrence of mucormycosis, a rare disease, in the general population was previously cited as 0.005 to 1.7 per million population. ${ }^{1}$ But the prevalence of mucormycosis in India is approximately 0.14 cases per 1000 population, about 80 times the prevalence in developed countries. ${ }^{2}$ The most common clinical form of this fungal infection is rhino-cerebral mucormycosis. ${ }^{3}$ Corona virus associated mucormycosis arose in India as a challenge during the second wave of COVID-19 pandemic. In this case series we describe 10 cases of mucormycosis including presentation, investigation, management and follow up.

\section{CASE SERIES}

\section{Case 1}

A 56-year-old lady, known diabetic with history of category B COVID infection presented with complaints of headache and pain around right eye after 20 days of COVID positivity. Diagnostic nasal endoscopy showed purulent nasal discharge in right nasal cavity with oedematous nasal mucosa. Her computed tomography paranasal sinus (CT PNS) showed right maxillary, ethmoid, frontal and sphenoid sinusitis with obliteration of right osteomeatal complex. Magnetic resonance imaging (MRI) brain revealed enhancing irregular mucosal thickening, soft tissue and retained secretions in right maxillary sinus extending to right nasal cavity, ethmoids with subtle erosion of right maxillary sinus with extension to pterygopalatine fossa, orbital apex. She was managed with endoscopic medial maxillectomy and liposomal amphotericin B. Local application of amphotericin was also done. She improved significantly. Her repeat biopsy under nasal endoscopy was normal showing healthy nasal mucosa with no evidence of fungal elements. She is asymptomatic now at four months follow up.

\section{Case 2}

A middle-aged female, known diabetic and post COVID presented with nasal block. Nasal endoscopy showed cheesy fungal material in left middle meatus and polypoid nasal mucosa. Specimen from left maxillary sinus showed entangled and broad aseptate fungal hyphae with acute angulation amidst dense inflammatory cells. Necrosis 
along with necrotic bone fragments were noted. Her MRI brain showed heterogeneously enhancing soft tissue mucosal thickening involving maxillary, frontal, ethmoidal and sphenoid sinuses on left side with intracranial extension of the lesion in basifrontal lobe through cribriform plate. There was small subacute haemorrhage in left frontal lobe. All these findings were suggestive of inflammatory fungal sinusitis consistent with mucormycosis. She underwent endoscopic nasal debridement and was given liposomal amphotericin B followed by oral posaconazole for 1 month. She improved symptomatically and is on follow up for four months. Her nasal endoscopy on follow up was normal and staining from the nasal mucosa did not show any fungal elements.

\section{Case 3}

An elderly male patient, known diabetic and hypertensive who had taken intensive care unit (ICU) care for COVID19 infection presented within 2 weeks with complaints of difficulty in opening both eyes, right sided facial pain and right sided loss of vision along with nasal obstruction, nasal discharge and epistaxis. His nasal endoscopy revealed blackish discolouration of both middle turbinates and crusts in bilateral middle meatus. MRI orbit with PNS showed mucosal thickening in bilateral paranasal sinuses, nonenhancing lesions in bilateral middle and left inferior turbinates. On ophthalmologic examination, he had lost perception of light in both eyes and ocular movements were restricted in all directions. Biopsy from the nasal tissue showed necrosis, exudate and abundant mucormycosis with tissue and bone invasion. $\mathrm{He}$ underwent complete endoscopic debridement including removal of medial wall of orbit. Patient completed a total dose of $5 \mathrm{~g}$ of amphotericin $\mathrm{B}$ and then changed to oral posaconazole. But his follow up after 1 month showed crusts in both nasal cavities suggestive of recurrence. Fungal stain from nasal mucosa showed aseptate hyphae which were typical of mucormycosis.

\section{Case 4}

A 56-year-old male patient, diabetic and hypertensive turned COVID positive and was under treatment. Two weeks after becoming COVID negative he presented with complaints of nasal congestion and headache. His diagnostic nasal endoscopy revealed black crusts in both nasal cavities. His CT PNS showed mucosal thickening in bilateral maxillary sinuses, bilateral anterior ethmoid air cells, frontal sinus and left sphenoid sinus. Fungal stain from the nasal mucosa showed both aseptate and septate fungal hyphae. Fungal culture and histopathologic examination were suggestive of mixed infection of aspergillus and mucor. Complete surgical debridement of the involved area was done. He was started on liposomal amphotericin B injection along with antibiotics. Frequent endoscopy and local application of antifungals were also done. He developed acute kidney injury after using amphotericin and hence withheld for few days and restarted when his renal parameters became normal. His nasal endoscopy showed complete clearance and he was symptomatically better. But he developed a sudden cardiac arrest and succumbed to death. The most probable cause was acute myocardial infection due to the hypercoagulable state associated with COVID infection.

\section{Case 5}

An elderly post COVID lady, diabetic and hypertensive, presented with history of headache, multiple episodes of focal seizures and weakness. CT brain showed acute infarct in left corona radiata and temporal lobe. There was B/L maxillary, ethmoid and sphenoid inflammatory mucosal thickening. MRI brain showed multiple acute infarcts in left temporoparietal region. There was optic nerve hyperintensity on left side. Magnetic resonance angiography (MRA) showed left internal carotid artery (ICA) involvement. Her nasal endoscopy revealed crusts. Fungal staining showed aseptate hyphae. She underwent transnasal decompression and was started on liposomal amphotericin B. She developed a cerebrovascular accident resulting in hemiparesis and later succumbed to death.

\section{Case 6}

A 57-year-old male patient, known diabetic and hypertensive presented with history of blurred vision and ptosis. At the time of admission to hospital, he was detected as COVID positive. Nasal endoscopy showed crusts in both nasal cavities. CT PNS showed mucosal thickening in right maxillary and ethmoid sinuses with hyperdensities. MRI brain with orbit was consistent with mucormycosis with infiltration of cavernous sinus and orbital apex. His fungal stain and histopathology were consistent with mucormycosis. He was started on liposomal amphotericin B. He underwent complete surgical debridement under nasal endoscopy. But his disease progressed rapidly. He developed cerebrovascular accident. He was in ventilatory support for many days and later succumbed to death.

\section{Case 7}

A middle-aged man, known diabetic who suffered COVID pneumonia presented 2 months later with complaints of bilateral eyelid swelling and pain on the right side of the face. His nasal endoscopy showed black crusts in both nasal cavities. He was diagnosed with sinonasal mucormycosis with optic neuritis and underwent endoscopic sinus surgery. Diagnosis was confirmed by calcofluor staining and histopathologic examination of the postoperative specimen from sinuses. He was given liposomal amphotericin B and he showed significant improvement. He is asymptomatic on follow up.

\section{Case 8}

A middle-aged male patient, known case of diabetes, hypertension, chronic liver disease with portal hypertension, alcohol dependence took treatment for 
headache and two episodes of seizure. He didn't have any previous history of COVID and his COVID reverse transcription polymerase chain reaction (RTPCR) was negative. MRI brain showed ill-defined enhancing lesion involving ethmoid sinuses, eroding cribriform plate and extending to anterior cranial fossa with intraparenchymal hematoma and extra axial collection. Bifrontal craniotomy and evacuation was done. Histopathology of the brain specimen showed fungal hyphae with morphology suggestive of mucormycosis. GeneXpert for Mycobacterium tuberculosis (MTB) was reported as low positive. He was started on liposomal amphotericin B. He had recurrent episodes of hypokalemia while on amphotericin B which needed correction. Later he became symptomatically better and was shifted to oral posaconazole. His nasal endoscopy became normal. On 4 months follow up he is, asymptomatic and is on treatment for TB meningitis.

\section{Case 9}

A middle-aged lady, known case of diabetes mellitus with no history of COVID presented with complaints of nasal discharge, nasal blockage and headache. Her CT PNS showed features of pansinusitis. Hyperdense material was noted in bilateral maxillary sinuses and overlying sinus walls appeared thickened with sclerotic changes. She underwent endoscopic sinus surgery. Her postoperative specimen from nasal mucosa showed features suggestive of mucormycosis on histopathology. She was started on liposomal amphotericin B. But she developed acute kidney injury and electrolyte imbalance, hence amphotericin was stopped. Her postoperative nasal endoscopy was normal. She was changed to oral posaconazole which was also stopped later as she couldn't tolerate it due to vomiting. On 4 months follow up she is asymptomatic and DNE normal.

\section{Case 10}

An elderly lady with no history of any comorbidities and with no history of COVID infection underwent functional endoscopic sinus surgery for sinusitis. Her CT PNS showed mucosal thickening with hyperdense contents in left maxillary sinus with bony wall sclerosis, suggestive of sinusitis, likely fungal etiology. Histopathology of the surgical specimen was suggestive of mucormycosis showing aseptate fungal hyphae with obtuse angle branching along with necrotic tissue. Potassium hydroxide $(\mathrm{KOH})$ stain from the nasal secretions showed aseptate fungal hyphae.

Hence, she was started on liposomal amphotericin B injection. During the course of treatment at hospital, she got infected with COVID-19, but had mild symptoms classified as category A. Her nasal endoscopy at the time of discharge from hospital was normal. She was advised to continue oral posaconazole, but discontinued due to financial constraints. She is on frequent follow up with nasal endoscopy.

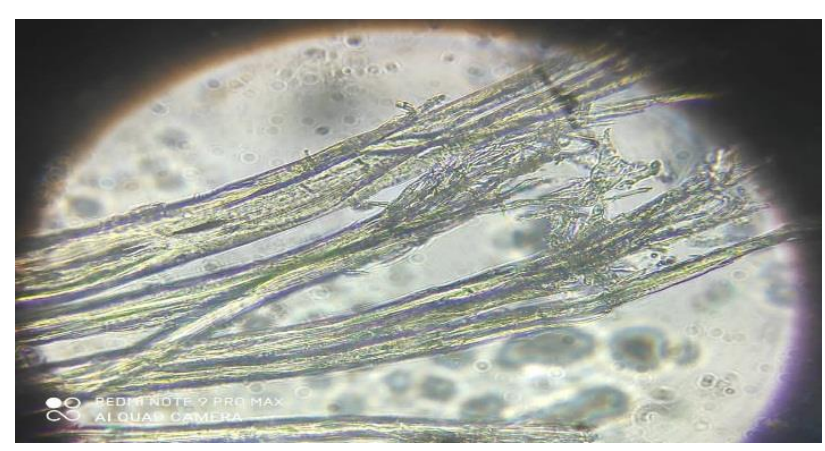

Figure 1: Aseptate fungal hyphae mixed with septate suggestive of mixed infection of mucormycosis with aspergillus. KOH stain of patient 4.

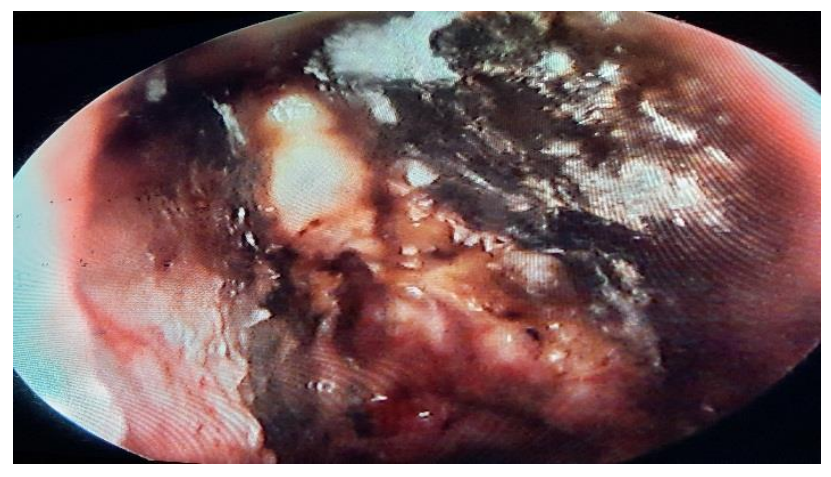

Figure 2: Black crusts present in both nasal cavities. Diagnostic nasal endoscopy of patient 4.

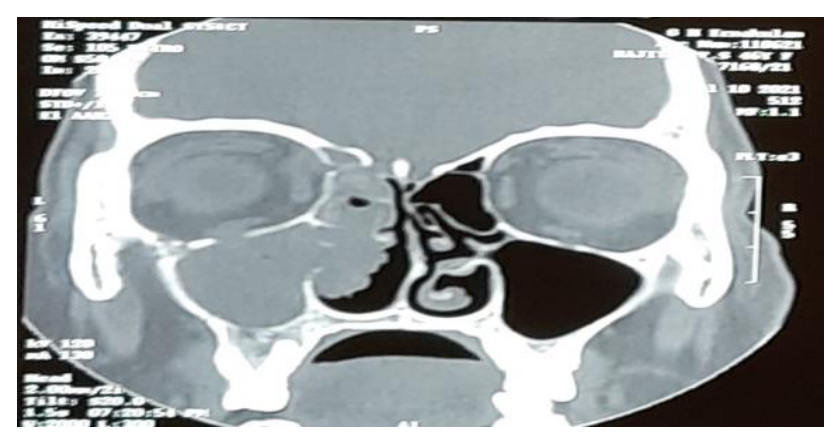

Figure 3: CT PNS- soft tissue opacification in all sinuses on one side with bony erosion of medial and posterolateral walls of maxillary sinus of patient 2 .

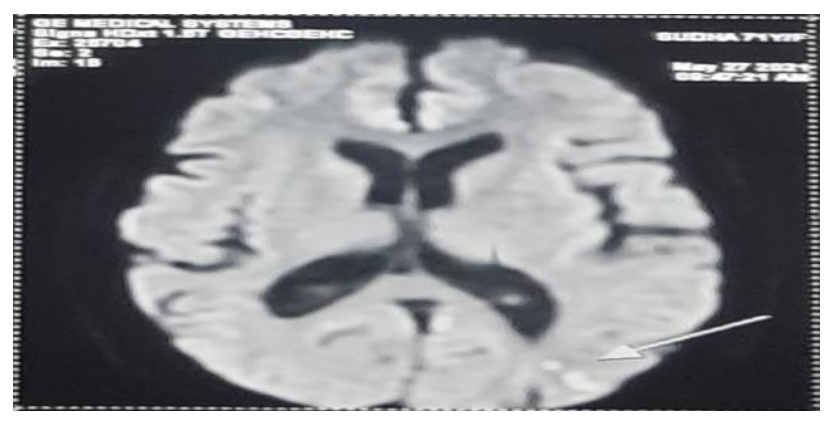

Figure 4: MRI brain: multiple acute infarcts in left temperoparaetal region. Optic nerve hyperintensity on left side. Left ICA involvement of patient 5. 
Table 1: History, DNE and imaging findings of patients with mucormycosis.

\begin{tabular}{|c|c|c|c|c|c|c|}
\hline $\begin{array}{l}\text { Patient } \\
\text { num- } \\
\text { ber }\end{array}$ & Age & Sex & $\begin{array}{l}\text { History } \\
\text { of } \\
\text { COVID }\end{array}$ & $\begin{array}{l}\text { Com- } \\
\text { orbid } \\
\text {-ities }\end{array}$ & DNE & Imaging \\
\hline 1 & 56 & Female & Present & DM & $\begin{array}{l}\text { Purulent nasal } \\
\text { discharge right } \\
\text { nasal cavity with } \\
\text { oedematous nasal } \\
\text { mucosa }\end{array}$ & $\begin{array}{l}\text { CT PNS - right maxillary, ethmoid, frontal and } \\
\text { sphenoid sinusitis with obliteration of right } \\
\text { osteomeatal complex; MRI brain: enhancing } \\
\text { irregular mucosal thickening, soft tissue and } \\
\text { retained secretions in right maxillary sinus } \\
\text { extending to right nasal cavity, ethmoids with } \\
\text { subtle erosion of right maxillary sinus with } \\
\text { extension to pterygopalatine fossa, orbital apex }\end{array}$ \\
\hline 2 & 46 & Female & Present & DM & $\begin{array}{l}\text { Polypoid mucosa, } \\
\text { cheesy fungal } \\
\text { material in left } \\
\text { middle meatus }\end{array}$ & $\begin{array}{l}\text { CT PNS- soft tissue opacification in all sinuses } \\
\text { on left side with bony erosion of medial and } \\
\text { posterolateral walls of maxillary sinus; MRI- } \\
\text { left frontal subacute haemorrhage, heterogenous } \\
\text { enhancing mucosal thickening in all sinuses on } \\
\text { left side with intracranial extension }\end{array}$ \\
\hline 3 & 70 & Male & Present & $\begin{array}{l}\text { DM, } \\
\text { HTN }\end{array}$ & $\begin{array}{l}\text { Blackish } \\
\text { discolouration in } \\
\mathrm{B} / \mathrm{L} \text { middle } \\
\text { turbinate, crusting } \\
\mathrm{B} / \mathrm{L} \text { middle meatus }\end{array}$ & $\begin{array}{l}\text { MRI orbits with PNS - mucosal thickening in } \\
\text { bilateral paranasal sinuses, non-enhancing } \\
\text { components in bilateral middle and left inferior } \\
\text { turbinates s/o invasive fungal sinusitis, } \\
\text { inflammatory changes in infraorbital regions, } \\
\text { left retrobulbar regions and oedema of left } \\
\text { extraocular muscles }\end{array}$ \\
\hline 4 & 57 & Male & Present & $\begin{array}{l}\text { DM, } \\
\text { HTN }\end{array}$ & $\begin{array}{l}\text { Black crusts present } \\
\text { in both nasal } \\
\text { cavities }\end{array}$ & $\begin{array}{l}\text { CT PNS: mucosal thickening B/L maxillary } \\
\text { sinus, B/L anterior ethmoid air cells, frontal } \\
\text { sinus, left sphenoid sinus }\end{array}$ \\
\hline 5 & 71 & Female & Absent & $\begin{array}{l}\text { DM, } \\
\text { HTN }\end{array}$ & $\begin{array}{l}\text { Polypoid mucosa } \\
\text { with secretions }\end{array}$ & $\begin{array}{l}\text { CT brain: acute infarct left corona radiata, } \\
\text { temporal lobe. B/L maxillary, ethmoid and } \\
\text { sphenoid inflammatory mucosal thickening } \\
\text { MRI brain: multiple acute infarcts in left } \\
\text { temperoparaetal optic nerve hyperintensity on } \\
\text { left side, left ICA involvement }\end{array}$ \\
\hline 6 & 57 & Male & Present & $\begin{array}{l}\text { DM, } \\
\text { HTN }\end{array}$ & Polypoid mucosa & $\begin{array}{l}\text { CT PNS: mucosal thickening in right maxillary, } \\
\text { ethmoid sinuses with hyperintensities noted } \\
\text { MRI brain: consistent with mucormycosis, } \\
\text { infiltration of cavernous sinus, orbital apex }\end{array}$ \\
\hline 7 & 48 & Male & Present & DM & $\begin{array}{l}\text { Black crusts in both } \\
\text { nasal cavities }\end{array}$ & \\
\hline 8 & 46 & Male & Absent & $\begin{array}{l}\text { DM, } \\
\text { HTN, } \\
\text { CLD }\end{array}$ & $\begin{array}{l}\text { Black crust in left } \\
\text { nasal cavity }\end{array}$ & $\begin{array}{l}\text { MRI brain: Ill-defined enhancing lesion } \\
\text { involving the ethmoid sinus, eroding cribriform } \\
\text { plate, extending to anterior cranial fossa }\end{array}$ \\
\hline 9 & 51 & Female & Absent & DM & $\begin{array}{l}\text { Bilateral nasal } \\
\text { polyps }\end{array}$ & Pansinusitis \\
\hline 10 & 71 & Female & Absent & Nil & $\begin{array}{l}\text { Polyps left nasal } \\
\text { cavity }\end{array}$ & $\begin{array}{l}\text { Mucosal thickening with hyperdense contents in } \\
\text { left maxillary sinus with bony wall sclerosis }\end{array}$ \\
\hline
\end{tabular}

Table 2: Microbiology, pathology, treatment and complications of patients with mucormycosis.

\begin{tabular}{|c|c|c|c|c|c|c|}
\hline $\begin{array}{l}\text { Patient } \\
\text { num- } \\
\text { ber }\end{array}$ & $\begin{array}{l}\text { Fungal stain } \\
\text { and } \\
\text { culture }\end{array}$ & HPE & $\begin{array}{l}\text { Involve } \\
\text {-ment }\end{array}$ & Treatment & Complications & Follow up \\
\hline 1 & & $\begin{array}{l}\text { Aseptate fungal } \\
\text { hyphae consistent } \\
\text { with mucormycosis }\end{array}$ & $\begin{array}{l}\text { Sinona- } \\
\text { sal }\end{array}$ & $\begin{array}{l}\text { Endoscopic medial } \\
\text { maxillectomy, } \\
\text { injection liposomal } \\
\text { amphotericin B }\end{array}$ & Hypokalemia & Asymptomatic \\
\hline
\end{tabular}




\begin{tabular}{|c|c|c|c|c|c|c|}
\hline $\begin{array}{l}\text { Patient } \\
\text { num- } \\
\text { ber }\end{array}$ & $\begin{array}{l}\text { Fungal stain } \\
\text { and } \\
\text { culture }\end{array}$ & HPE & $\begin{array}{l}\text { Involve } \\
\text {-ment }\end{array}$ & Treatment & Complications & Follow up \\
\hline 2 & $\begin{array}{l}\text { PAS positive } \\
\text { for fungal } \\
\text { profile with } \\
\text { morphology } \\
\text { s/o } \\
\text { aspergillosis } \\
\text { and mucor }\end{array}$ & $\begin{array}{l}\text { Necrosis, exudate } \\
\text { and abundant } \\
\text { mucormycosis with } \\
\text { tissue and bony } \\
\text { invasion }\end{array}$ & $\begin{array}{l}\text { Rhinoc } \\
\text {-erebral }\end{array}$ & $\begin{array}{l}\text { Endoscopic } \\
\text { debridement, } \\
\text { liposomal } \\
\text { amphotericin B } \\
\text { injection }\end{array}$ & & Asymptomatic \\
\hline 3 & & $\begin{array}{l}\text { HPE from brain } \\
\text { specimen: fungal } \\
\text { hyphae with } \\
\text { morphology } \\
\text { suggestive of } \\
\text { mucormycosis }\end{array}$ & $\begin{array}{l}\text { Rhino- } \\
\text { orbital }\end{array}$ & $\begin{array}{l}\text { Endoscopic } \\
\text { debridement, } \\
\text { injection liposomal } \\
\text { amphotericin B } \\
\text { followed by oral } \\
\text { posaconazole }\end{array}$ & $\begin{array}{l}\text { Loss of vision } \\
\text { bilateral, } \\
\text { hypokalemia } \\
\text { anaemia }\end{array}$ & $\begin{array}{l}\text { Crusts in nasal } \\
\text { cavity tested, } \\
\text { fungal stain } \\
\text { positive for } \\
\text { mucormycosis }\end{array}$ \\
\hline 4 & $\begin{array}{l}\text { Aseptate and } \\
\text { septate hyphae } \\
\text { seen }\end{array}$ & $\begin{array}{l}\text { Mixed infection of } \\
\text { aspergillus and } \\
\text { mucor }\end{array}$ & $\begin{array}{l}\text { Sinon- } \\
\text { asal }\end{array}$ & $\begin{array}{l}\text { Complete surgical } \\
\text { debridement, } \\
\text { liposomal } \\
\text { amphotericin B } \\
\text { injection }\end{array}$ & $\begin{array}{l}\text { Acute kidney } \\
\text { injury, sudden } \\
\text { cardiac arrest }\end{array}$ & Expired \\
\hline 5 & $\begin{array}{l}\text { Aseptate } \\
\text { hyphae }\end{array}$ & $\begin{array}{l}\text { HPE: suggestive of } \\
\text { mucormycosis }\end{array}$ & $\begin{array}{l}\text { Sinon- } \\
\text { asal }\end{array}$ & $\begin{array}{l}\text { Endoscopic } \\
\text { decompression, } \\
\text { injection liposomal } \\
\text { amphotericin B }\end{array}$ & $\begin{array}{l}\text { Acute kidney } \\
\text { injury, electrolyte } \\
\text { imbalance, had to } \\
\text { discontinue } \\
\text { antifungals }\end{array}$ & Asymptomatic \\
\hline 6 & $\begin{array}{l}\text { Aseptate } \\
\text { hyphae }\end{array}$ & $\begin{array}{l}\text { Inflammatory } \\
\text { fungal sinusitis } \\
\text { consistent with } \\
\text { mucormycosis }\end{array}$ & $\begin{array}{l}\text { Rhinoc } \\
\text {-erebral }\end{array}$ & $\begin{array}{l}\text { Endoscopic } \\
\text { debridement, } \\
\text { liposomal } \\
\text { amphotericin B } \\
\text { injection }\end{array}$ & $\begin{array}{l}\text { Cerebrovascular } \\
\text { accident }\end{array}$ & Expired \\
\hline 7 & $\begin{array}{l}\text { Calcofluor } \\
\text { stain: } \\
\text { suggestive of } \\
\text { mucormycosis }\end{array}$ & $\begin{array}{l}\text { Suggestive of } \\
\text { mucormycosis }\end{array}$ & $\begin{array}{l}\text { Rhino- } \\
\text { orbital }\end{array}$ & $\begin{array}{l}\text { Endoscopic sinus } \\
\text { surgery followed by } \\
\text { antifungals }\end{array}$ & Optic neuritis & Asymptomatic \\
\hline 8 & & $\begin{array}{l}\text { HPE from brain } \\
\text { specimen: fungal } \\
\text { hyphae with } \\
\text { morphology } \\
\text { suggestive of } \\
\text { mucormycosis }\end{array}$ & $\begin{array}{l}\text { Rhinoc } \\
\text {-erebral }\end{array}$ & $\begin{array}{l}\text { Bifrontal } \\
\text { craniotomy and } \\
\text { evacuation, } \\
\text { injection liposomal } \\
\text { amphotericin B, } \\
\text { oral posaconazole }\end{array}$ & $\begin{array}{l}\text { Recurrent } \\
\text { hypokalemia }\end{array}$ & $\begin{array}{l}\text { Asymptomatic } \\
\text { on ATT for } \\
\text { TB meningitis }\end{array}$ \\
\hline 9 & & & $\begin{array}{l}\text { Sinon- } \\
\text { asal }\end{array}$ & $\begin{array}{l}\text { FESS followed by } \\
\text { liposomal } \\
\text { amphotericin B for } \\
\text { few days, then oral } \\
\text { posaconazole }\end{array}$ & $\begin{array}{l}\text { Acute kidney } \\
\text { injury, electrolyte } \\
\text { imbalance }\end{array}$ & Asymptomatic \\
\hline 10 & $\begin{array}{l}\text { Aseptate } \\
\text { fungal hyphae } \\
\text { seen }\end{array}$ & Mucormycosis & $\begin{array}{l}\text { Sinon- } \\
\text { asal }\end{array}$ & $\begin{array}{l}\text { Endoscopic sinus } \\
\text { surgery, injection } \\
\text { liposomal } \\
\text { amphotericin B } \\
\text { followed by oral } \\
\text { posaconazole }\end{array}$ & $\begin{array}{l}\text { Infected with } \\
\text { COVID during } \\
\text { course of treatment }\end{array}$ & $\begin{array}{l}\text { Stopped } \\
\text { posaconazole } \\
\text { due to finan- } \\
\text { cial constrai- } \\
\text { nts, frequent } \\
\text { endoscopic } \\
\text { suction } \\
\text { clearance, } \\
\text { asymptomatic }\end{array}$ \\
\hline
\end{tabular}




\section{DISCUSSION}

Mucormycosis is an angioinvasive disease caused by fungi of the order Mucorales like Rhizopus, Mucor, Rhizomucor, Cunninghamella and Absidia. ${ }^{4}$ There had been a steep rise in cases of mucormycosis (black fungus infection) amid the second wave of COVID-19 pandemic in India. Because of its severe complications and associated higher fatality rate in post COVID-19 patients, this rare disease is now a notifiable disease in India. ${ }^{1}$ The triad of severe acute respiratory syndrome corona virus-2 (SARS-CoV-2), steroid and uncontrolled diabetes mellitus have contributed towards a significant increase in the incidence of angioinvasive maxillofacial mucormycosis. ${ }^{5}$ However, the presence of spores and other factors might play a role as well. The most common clinical form of mucormycosis is rhino-orbito-cerebral (44-49\%), followed by cutaneous (10-16\%), pulmonary (10-11\%), disseminated (6-11.6\%) and gastrointestinal (2-11\%) presentations. About $70 \%$ of rhinocerebral cases are found in diabetic patients. ${ }^{6}$

In rhinoorbitocerebral mucormycosis, infection begins in the nasal cavities and paranasal sinuses. The symptoms of mucormycosis include one-sided facial swelling, headache, fever, inflammation, eyelid drooping and black lesions inside the nasal cavity. ${ }^{7}$ When there is extensive central nervous system involvement, the angioinvasive nature of the fungus may result in cavernous sinus thrombosis and internal carotid artery encasement and thrombosis with resultant extensive cerebral infarctions. Methods for diagnosing mucormycosis include histopathology, direct testing, and culture of clinical specimens. The biopsy should demonstrate the characteristic wide, ribbon-like, aseptate hyphal elements that branch at right angles. The organisms are often surrounded by extensive necrotic debris. ${ }^{6}$

Reasons for increase in mucormycosis in COVID-19 patients include hyperglycemia due to uncontrolled preexisting diabetes, rampant overuse and irrational use of steroids in management of COVID-19, new onset diabetes due to steroid overuse or severe cases of COVID-19, prolonged ICU stay and irrational use of broad-spectrum antibiotics, pre-existing co-morbidities, and breakthrough infections in patients on antifungal prophylaxis. ${ }^{8}$

The management of mucormycosis is usually difficult and requires urgent medical management and surgical debridement. The choice of drug to treat mucormycosis is amphotericin B. In case of intolerance of the treatment regimen or generalised weakness of the patient, azole compounds such as posaconazole and isavuconazole can be used. ${ }^{9}$

The fact that India turned out to be the most affected country might be probably related to climatic, socioeconomic, scarce hygienic conditions and diagnostic delay. ${ }^{6}$ Malnutrition and undiagnosed diabetes mellitus in India also contribute to this (10).
The outcome was favourable for patients who had surgical debridement in three case series. ${ }^{11-13}$ The overall survival rate of patients with mucormycosis is approximately $50 \%$, although survival rates of up to $85 \%$ have been reported more recently with better survival in rhinocerebral form. ${ }^{6}$ The prognosis is much better if the disease has not penetrated beyond the sinus prior to surgical debridement; in local sinonasal disease, the mortality has been reported to be less than $10 \% .{ }^{14}$ Early diagnosis and urgent antifungal treatment associated to surgery are of extreme importance. ${ }^{15}$

In this paper we report 10 cases of histopathologically proven rhinofacial mucormycosis. Only 7 of the 10 cases had previous history of COVID-19 before the onset of mucormycosis. The mean age of presentation was 57.3 years. There were 5 male and 5 female patients each. The major risk factor diabetes was detected in nine of the ten patients. The typical presentation of black nasal crusts was seen only in three patients. Two of our patients developed cerebrovascular accidents following cerebral involvement and both of them succumbed to death. All patients underwent surgery followed by antifungal therapy. Less severe symptoms and better prognosis were observed in patients without previous history of COVID-19.

In our study, mortality was $30 \%$. Of the survivors one patient showed recurrence. All other patients were asymptomatic on last follow up. All the three mortalities were reported in COVID positive patients. Lesser severity of symptoms and better prognosis in non-COVID patients may be due to better immunity in them. On comparing the survival rate among both groups, all mortalities were observed in COVID positive patients. But this did not reach statistical significance. A p value of 0.175 was observed as per Chi square test which is not significant. This may be because of small sample size. The fact that 9 out of our ten patients including 2 out of 3 COVID negative patients were diabetic might have also contributed to the non-significant difference between the two groups. A study by Mignogna and Fortuna et al of mucormycosis in immunocompetent patients have shown good results with all of them having disease limited to maxillary sinus surviving with amphotericin B alone. ${ }^{16}$

\section{CONCLUSION}

In the present scenario rhinocerebral mucormycosis can occur in people with or without previous history of COVID infection. Presentation may not be always typical. The factors required for success in mucormycosis management are early suspicion leading to timely diagnosis, control of predisposing conditions mainly diabetes, complete surgical debridement and appropriate antifungal therapy.

\section{ACKNOWLEDGEMENTS}

Authors would like to acknowledge Dr. Sreeram Prasad A. V., consultant neurologist, Lourdes Hospital, Ernakulam; Dr. Saju K. G., consultant ENT surgeon, District Hospital, 
Thrissur; Dr. Sujit Harshan, chief dental surgeon, Dr. Meena Beevi, consultant pathologist, and Dr. Arya R. V., junior consultant microbiology, General Hospital, Ernakulam.

\section{Funding: No funding sources}

Conflict of interest: None declared

Ethical approval: Not required

\section{REFERENCES}

1. Al-Tawfiq JA, Alhumaid S, Alshukairi AN, Temsah MH, Barry M, Al Mutair A, et al. COVID-19 and mucormycosis superinfection: the perfect storm. Infection. 2021;49(5):833-53.

2. Skiada A, Pavleas I, Drogari-Apiranthitou M. Epidemiology and diagnosis of mucormycosis: an update. J Fungi. 2020;6:265.

3. Mohammadi F, Badri M, Safari S, Hemmat N. A case report of rhino-facial mucormycosis in a non-diabetic patient with COVID-19: a systematic review of literature and current update. BMC Infect Dis. 2021;21:906.

4. Revannavar SM, Supriya PS, Samaga L, Vineeth VK. COVID-19 triggering mucormycosis in a susceptible patient: a new phenomenon in the developing world? BMJ Case Rep. 2021;14:e241663.

5. Moorthy A, Gaikwad R, Krishna S, Hegde R, Tripathi KK, Kale PG, et al. SARS-CoV-2, uncontrolled diabetes and corticosteroids - an unholy trinity in invasive fungal infections of the maxillofacial region? A retrospective, multi-centric analysis. J Maxillofac Oral Surg. 2021;20(3):1-8.

6. Spellberg B, Edwards J, Ibrahim A. Novel Perspectives on Mucormycosis: Pathophysiology, Presentation, and Management Clinical microbiology reviews. 2005;18(3):556-69.

7. Ferguson BJ. Mucormycosis of the nose and paranasal sinuses. Otolaryngol Clin $\mathrm{N}$ Am. 2000;33(2):349-65.

8. Directorate General of Health Services. Guideline for management of Mucormycosis in COVID - 19 patient. 2021. Available at: https://dghs.gov.in. Accessed on 15 October 2021.

9. Cornely OA, Alastruey-Izquierdo A, Arenz D, Chen SC, Dannaoui E, Hochhegger B, et al. Global guideline for the diagnosis and management of mucormycosis: an initiative of the European Confederation of Medical Mycology in cooperation with the Mycoses Study Group Education and Research Consortium. Lancet Infect Dis. 2019;19(12):405-21.

10. Michael RC, Michael JS, Ashbee RH, Mathews MS. Mycological profile of fungal sinusitis: An audit of specimens over a 7-year period in a tertiary care hospital in Tamil Nadu. Indian J Pathol Microbiol. 2008;51:493-6.

11. Sen M, Lahane S, Lahane TP, Parekh R, Honavar SG. Mucor in a viral land: a tale of two pathogens. Indian J Ophthalmol. 2021;69:244-52.

12. Sharma S, Grover M, Bhargava S, Samdani S, Kataria T. Post coronavirus disease mucormycosis: a deadly addition to the pandemic spectrum. J Laryngol Otol. 2021;135(5):442-7.

13. Ravani SA, Agrawal GA, Leuva PA, Modi PH, Amin KD. Rise of the phoenix: Mucormycosis in COVID19 times. Indian J Ophthalmol. 2021;69:1563-8.

14. Nithyanandam S, Jacob MS, Battu RR, Thomas RK, Correa MA, D'Souza O. Rhino-orbito-cerebral mucormycosis. A retrospective analysis of clinical features and treatment outcomes. Indian J Ophthalmol. 2003;51:231-3.

15. Jiang N, Zhao G, Yang S, Lin J, Hu L, Che C, Wang $\mathrm{Q}, \mathrm{Xu} \mathrm{Q}$. A retrospective analysis of eleven cases of invasive rhino-orbito-cerebral mucormycosis presented with orbital apex syndrome initially. BMC Ophthalmol. 2016;16:10.

16. Mignogna MD, Fortuna G, Leuci S, Adamo D, Ruoppo E, Siano M, Mariani U. Mucormycosis in immunocompetent patients: a case-series of patients with maxillary sinus involvement and a critical review of the literature. Int $J$ Infect Dis. 2011;15(8):533-40.

Cite this article as: Sreenath S, Ravi AKA. Experiences with mucormycosis during COVID times in a government hospital in Kerala - a case series. Int J Otorhinolaryngol Head Neck Surg 2022;8:252-8. 